\title{
MEAN BASIC DENSITY AND ITS AXIAL VARIATION IN SCOTS PINE, NORWAY SPRUCE AND BIRCH STEMS
}

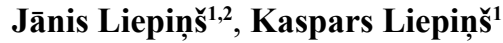 \\ ${ }^{1}$ Latvian State Forest Research Institute 'Silava' \\ ${ }^{2}$ Latvia University of Agriculture \\ janis.liepins@silava.lv; kaspars.liepins@silava.lv
}

\begin{abstract}
The objective of this study is to evaluate the performance of models developed by Repola (2006) to estimate the vertical changes of the basic density of Scots pine (Pinus sylvestris L.), Norway spruce (Picea abies [L.] Karst), and birch spp. (mainly Betula pendula Roth) stemwood in the forests of Latvia and to develop a model for the estimation of average knot-free stem density with bark (SD) using diameter at breast height as an independent variable. The study material comprised a total of 81 spruce, 102 pine, and 105 birch stems representing a wide range of tree growing conditions in Latvia and covering all age classes.

The knot-free stemwood density (SWD) of pine and birch demonstrate strong vertical dependence along the stem, while for spruce the variation pattern was less pronounced and seemed to be nearly constant along the stem. The SWD estimated by Repola's models was $4.3 \%$ lower for spruce, but $3.4 \%$ higher for pine and $2.2 \%$ for birch comparing to average values obtained in this study.

Sigmoidal regression equations constructed in our study explained $67 \%, 27 \%$ and $54 \%$ of variations for predicting SD for pine, spruce and birch, respectively. Birch stemwood has a highest basic SWD $-470 \mathrm{~kg} \mathrm{~m}^{-3}$, followed by pine $-397 \mathrm{~kg} \mathrm{~m}^{-3}$ and spruce $-385 \mathrm{~kg} \mathrm{~m}^{-3}$. According to our results, the birch bark turned to be denser than the birch stemwood, being vice versa for the studied coniferous species.
\end{abstract}

Key words: stemwood density, bark density, density variations, pinus silvestris, picea abies, betula pendula.

\section{Introduction}

Basic density is one of the key wood properties for evaluation of the mechanical wood qualities for commercial use, determining the suitability of wood for different end use purposes. Wood density has numerous variation sources and is well correlated to many other physical properties of wood, like strength, stiffness and performance in use (Saranpää, 2003). It is a key variable for the estimation of tree mass (Henry et al., 2010) Low density wood is more suitable for pulp and paper products than for structural timber, where high density and strength is preferred (Saranpää, 2003).

Worldwide, there has been an increasing focus on the carbon footprint of buildings and recognition that design professionals are uniquely positioned to reduce greenhouse gases in the atmosphere by creating high performance structures using wood (Cabeza et al., 2013; Gustavsson, Pingoud, \& Sathre, 2006). The density of wood tells how much carbon the tree has allocated into the wood (Chave, 2005); denser wood products stored more carbon. Carbon constitutes approximately $50 \%$ of the dry mass of wood and when wood is used to produce products, the carbon is stored for life in that product.

As it is presented in Figure 1, one of the most important factors affecting wood density is the moisture content. There are varieties of wood density definitions in reference to moisture content. Foresters usually measure the air-dried or green weight of the wood. In addition, there are different understandings of air-dry weight - the water content remaining in the wood may be $12 \%$ or $15 \%$ (Chave, 2005).
Information about correct wood basic density is needed to determine the stem biomass. In many studies, oven-dry stem biomass (water content is $0 \%$ ) has been determined by multiplying the stem volume by the average stem wood basic density e.g. (Repola, 2008; Repola, 2009; Skovsgaard, Bald, \& Nord-Larsen, 2011). Wood density interpretation and comparison at divergent meanings causes considerable misunderstandings in the literature. When reporting wood density, the moisture content at which the weight and volume of wood were measured must be indicated in the manuscript, as well the drying temperature when wood density is measured, since the influence of different drying temperatures on a dry weight determination has been reported (Petersson \& Stahl, 2006). Below $100{ }^{\circ} \mathrm{C}$ the wood sample may not be dried completely, and above $105{ }^{\circ} \mathrm{C}$ it may char (Ilic et al., 2000).

Different methods have been applied to determine the average wood density of the stem. In biomass studies, the average stem density has been most commonly derived from sample disks taken at different heights along the stem by destructive sampling method (Repola, 2006; Repola, 2008; Repola, 2009). An alternative method is to use the increment borer extracting a small dowel-like piece from a tree (Chave, 2005; Liepins \& Rieksts-Riekstins, 2013). The within-tree variation of wood density can be divided into radial variation from the pith to the cambium and axial variation along the stem (Jyske, Mäkinen, \& Saranpää, 2008), and these variation patterns need to be considered when estimating the weighted density from wood samples. 


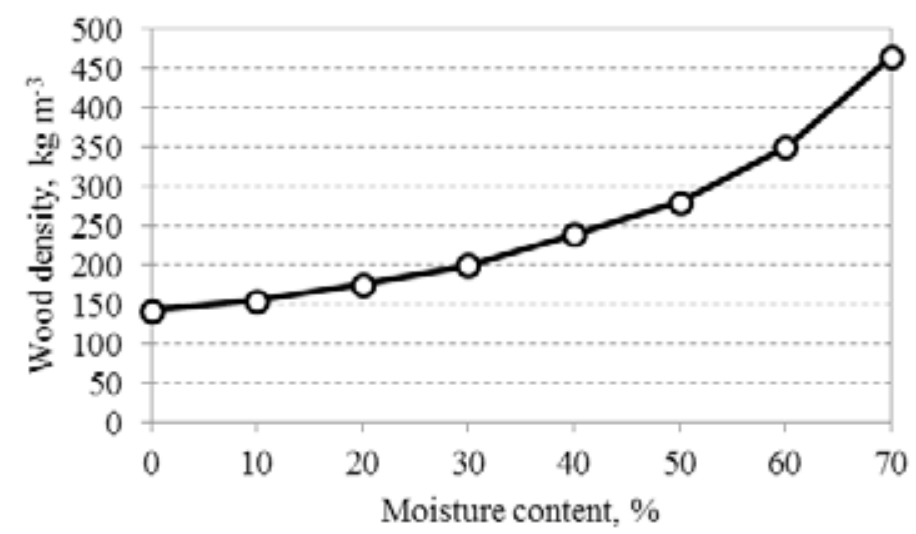

Figure 1. Relationship between wood density and absolute moisture content in whole tree Sitka spruce wood (Kofman \& Kent, 2007).

In the Nordic and Baltic countries, Scots pine (Pinus sylvestris L.), Norway spruce (Picea abies [L.] Karst), and silver birch (Betula pendula Roth.) are tree species with high industrial and ecological importance. Variation of basic stem density from the stem base to the tree top of these species has been studied in Finland (Repola, 2006) deriving models to describe vertical dependence of density along the stem and average stem density. Repola (2006) found that birch and pine wood had strong vertical dependence of density, encountering a downward trend from base to top along the stem while spruce had a moderate vertical variation.

Despite the importance of the aforementioned species, so far the average basic density values obtained in Russia and European countries have been exploited in Latvia, and there is no information about the most suitable one for local conditions (Millers \& Magaznieks, 2012). Earlier studies of wood density variations within silver birch stems (Liepins \& Rieksts-Riekstins, 2013) showed that Repola's model had a good fit for empirical data collected in birch plantations on former farmlands in Latvia, reporting the average wood density values that are similar to those achieved in other studies in the Baltic sea region.

The aim of this study is to evaluate the performance of models developed by Repola (2006) to estimate vertical changes of the basic density of Scots pine, Norway spruce, and birch stems in forests of Latvia and to develop a model for estimation of knot-free stem density with bark (SD) using diameter at breast height (D) as an independent variable.

\section{Materials and Methods}

The study material comprised a total of 81 spruce, 102 pine, and 105 birch stems representing a wide range of tree growing conditions in Latvia and covering all age classes (Table 1). In each of the selected forest stands three sample trees representing the range of social status of the dominant trees were felled down. Empirical material is also described in previous studies (Liepiňš \& Liepiňš, 2015). The tree stems were cross-cut into $1 \mathrm{~m}$ or $2 \mathrm{~m}$ sections towards the top depending on the stem length $(1 \mathrm{~m}$ sections for stems with a length below $20 \mathrm{~m}, 2 \mathrm{~m}$ sections for stems with length over $20 \mathrm{~m}$ ). To obtain the average density of the stem and to describe vertical changes of density, sample discs were collected at the beginning of each stem section as well at the height of $1.3 \mathrm{~m}$ and at the midpoint of the first section. The vertical location of samples along the stem was expressed as the relative height ranged from 0 (butt) to 1 (top). The sample disks were stored in plastic bags and transported to the laboratory for measurements of dry weight and basic density.

In the present study, basic density is technically defined as the ratio of the oven-dry mass of a wood sample divided by the mass of water displaced by its green volume. The specimens for the basic density measurements were prepared from the sample discs using modified scheme reported in Herajarvi (2004) studies. The wood and bark specimens were measured separately and density was determined using Precisa XB 220A scales equipped with a Precisa density determination set (Part no: 350-8556). For the calculation of basic (water content is $0 \%$ ) wood and bark density, all specimens were dried at $105^{\circ} \mathrm{C}$ until a constant weight was achieved. Before the density measurements were conducted, all specimens were saturated with water by immersion for 24 hours (Ilic et al., 2000).

The weighted average formula was used to calculate the mean basic density of each sample disc from the specimens and their corresponding areas. The volume of each stem section (between two sample discs) was estimated using Smalian's approach often applied in similar studies e.g. (Smith et al., 2014). The 
Table 1

Sample tree characteristics by tree species

\begin{tabular}{|c|c|c|c|c|c|c|c|c|c|}
\hline & \multicolumn{3}{|c|}{ Pinus sylvestris } & \multicolumn{3}{c|}{ Picea abies } & \multicolumn{3}{c|}{ Betula spp. } \\
\cline { 2 - 11 } & $\mathrm{D}, \mathrm{cm}$ & $\mathrm{L}, \mathrm{m}$ & $\mathrm{T}$, year & $\mathrm{D}, \mathrm{cm}$ & $\mathrm{L}, \mathrm{m}$ & $\mathrm{T}$, year & $\mathrm{D}, \mathrm{cm}$ & $\mathrm{L}, \mathrm{m}$ & $\mathrm{T}$, year \\
\hline Mean & 19.0 & 17.3 & 54 & 17.5 & 16.6 & 41 & 14.7 & 18.1 & 35 \\
\hline Std & 9.4 & 9.2 & 39.1 & 9.0 & 8.9 & 26.9 & 7.5 & 8.1 & 23.6 \\
\hline Min & 1.5 & 1.9 & 6 & 2.3 & 2.8 & 9 & 2.7 & 4.8 & 8 \\
\hline Max & 45.2 & 34.5 & 141 & 36.3 & 30.8 & 97 & 37.1 & 32.3 & 92 \\
\hline
\end{tabular}

$\mathrm{D}$ - diameter at breast height, $\mathrm{L}$ - stem length, $\mathrm{T}$ - tree age (forest inventory data).

average density of each stem section was calculated as mean from both sample discs at the ends of section, except top sections where only base sample disc was used. The weighted average formula was used to calculate the mean density of each stem from the average density of sections and their corresponding volumes.

The linear mixed models proposed by Repola (2006) were used to calculate vertical dependence of the knot-free stemwood density (SWD) of Scots pine, Norway spruce, and birch stems on the basis of measured tree variables (D, tree height, tree age, relative height of position in tree) in this study.

Sigmoidal regression equations were constructed to estimate SD using tree D as the only variable. The general form of the equation is as follows:

$$
Y=\beta_{1} /\left(1+\beta_{2} e^{-\beta_{3} D}\right)
$$

Where: $\mathrm{Y}$ is the average stem density $\left(\mathrm{kg} \mathrm{m}^{-3}\right), \mathrm{D}$ is breast height diameter $(\mathrm{cm}), \beta_{1}, \beta_{2}$ and $\beta_{3}$ are the coefficients.

Regression analyses and descriptive statistics were carried out using the CurveExpert Professional 2.2 software.

\section{Results and Discussion}

The results are indicating the distinctive patterns of SWD along the stem for the studied tree species (Figure 2). Pine and birch demonstrated strong vertical dependence, reducing the SWD with an increase in stem relative height. For spruce the axial variation of SWD was less pronounced and seemed to be nearly constant from the stump height to the top of tree which is consistent with the results reported in previous studies (Hakkila, 1998; Repola, 2006; Jyske et al., 2008). Our findings and discovered SWD variation trends for pine, spruce and birch stems are in line with Repola's (2006) findings who also reported the distinct variations in wood density with an increasing tree relative height.

In our study, the SWD estimated for our data set with Repola's models was systematically lower for spruce (average 4.3\%) but not for other species (Figure 2). Pine and birch SWD, estimated with Repola's models, resulted in an overestimation (average $3.4 \%$ and $2.2 \%$, respectively) mostly in the upper part of stems. Different D distribution of the sample trees can be one of the reasons why models resulted in a small overestimation for pine and birch. Repola's data set did not include the stems from young stands, and the minimum $\mathrm{D}$ of the sample trees was $6 \mathrm{~cm}$. In our study, an equal number of trees of
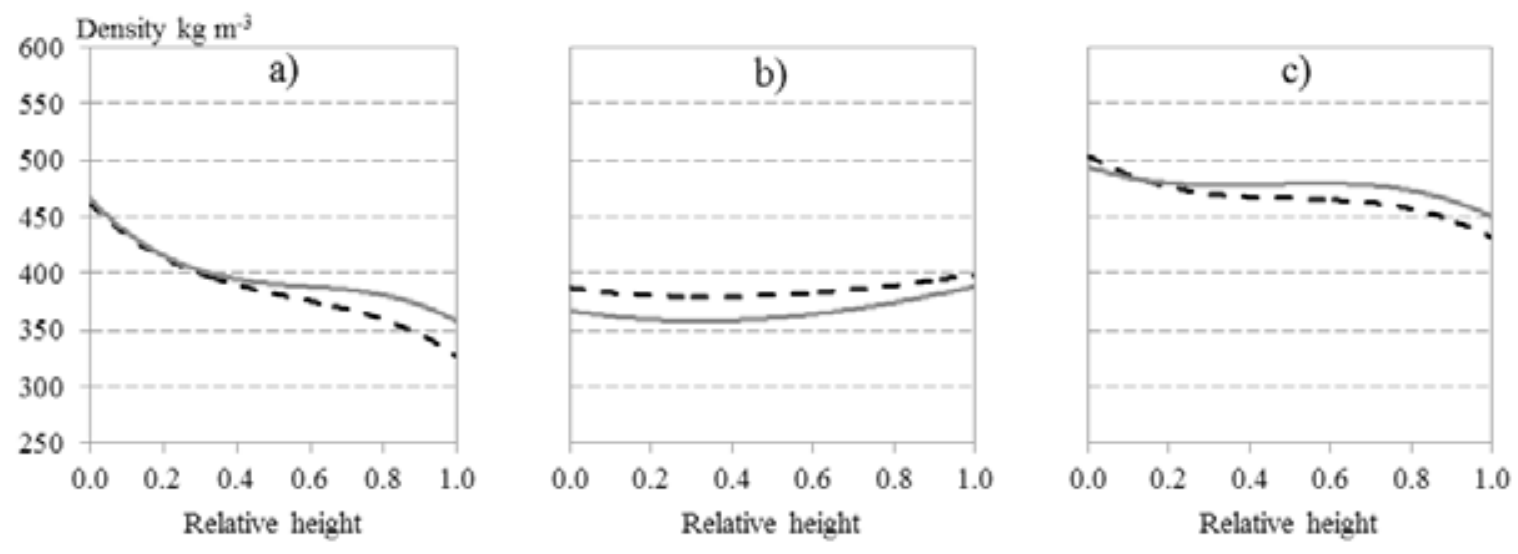

Figure 2. Predictions of SWD in the vertical direction along pine (a), spruce (b) and birch (c) stems according to Repola's (2006) models (grey line) and our measurements (black, dashed line). 
determined age groups (young, middle aged, mature) were selected and minimum $\mathrm{D}$ of the trees was 1.5 $2.7 \mathrm{~cm}$ depending on the species (Table 1). Generally, SWD is higher for mature trees than for young trees, but these variations are also depending on the interactions of the species and the environment (Ilic et al., 2000; Saranpää, 2003; Jyske et al., 2008; Millers \& Magaznieks, 2012).

The average SWD for spruce reported by Repola (2006) is $385.3 \mathrm{~kg} \mathrm{~m}^{-3}$, being very close to the value achieved in our study $-378.0 \mathrm{~kg} \mathrm{~m}^{-3}$. The reasons why the use of Repola's model produced markedly lower SWD for spruce $\left(359.5 \mathrm{~kg} \mathrm{~m}^{-3}\right)$ are unclear, especially taking into account that for pine and birch the aforementioned model predicted very similar values with those reported in his study. If plotted against our results (Figure 2), the predicted SWD values according to Repola's model along pine and birch stems are showing very good fit for pine and birch but not for spruce.

In both studies, the density estimates were based on knot-free sample disks, therefore a $1 \%$ correction is recommended in order to obtain realistic values (Repola, 2006). Tree branches are always denser than wood, for instance, branch density for spruce decreased along the crown level and was about 15 $20 \%$ higher than wood density (Dibdiakova \& Vadla, 2012).

It has to be noted that there are numerous studies performed on SWD and its variations worldwide, however, the mean stem density (SD) has been studied much rarer. In terms of SWD, Rikala (2003) found that $3 \%$ and $50 \%$ of the variations could be explained for basic density as a function of relative height for spruce and pine, respectively. For spruce the largest (49$80 \%$ ) variation in SWD was found within the annual rings (Jyske et al., 2008). The predictive models were developed for average SWD using density data from one or more cross-sectional discs (Singh, 1984; Repola, 2006). Applying of models may be a more accurate method than the use of average basic density values to estimate mass of stem or wood sample due to the large variations in wood density. However, time consuming measurements needed for estimation of some key variables is the reason why many of the published functions are not practiced. Mostly the functions are focused only on the estimation of stemwood density; however, the bark should be included in the models if the calculation of whole stem biomass is the aim, as it is in the case of carbon accounting. Prediction equations based on commonly measured tree variables, such as $\mathrm{D}$, tree height and age, would be the most useful and convenient ones to obtain the estimates of mean stem density. Among those, $\mathrm{D}$ is the easiest variable to measure; therefore it was chosen in this study.

In our investigation, the sigmoid growth model widely used in investigations of growth of forest trees and to describe various biological processes (Birch, 1999; Pödör, Manninger, \& Jereb, 2014) was applied. The modified form of the sigmodal model (equation 1) gives three basic curve parameters that can be used in further investigations on mean SD in pine, spruce and birch stems. The relationship between mean SD and D and the general form of basic density curves is presented in Figure 3. A wide prediction band in Figure 3 indicates considerable fluctuations of basic density that is influenced by other factors. The summary of fit statistics (Table 2) displays that $67 \%$, $27 \%$ and $54 \%$ of the variations could be explained with basic density as a function of $\mathrm{D}$ for pine, spruce and birch, respectively. The confidence bands for all species demonstrate that standard error of the regression is greater at small and large tree $\mathrm{D}$, likely because of the smaller number of measurements at given dimensions (Figure 3).

There is a strong evidence of SD variation depending on tree dimensions and, consequently, on the tree age being more obvious for the pine. SD of young pine was $281 \mathrm{~kg} \mathrm{~m}^{-3}$ that is $34.2 \%$ less than for matured trees $\left(427 \mathrm{~kg} \mathrm{~m}^{-3}\right)$. There is the same regularity for spruce and birch, however, the difference in SD for young and matured trees is markedly less pronounced. The range for mean values for spruce was $335 \mathrm{~kg}$ $\mathrm{m}^{-3}$ for young trees and $398 \mathrm{~kg} \mathrm{~m}^{-3}$ for matured trees (difference $15.8 \%$ ) while the same values for birch $416-524 \mathrm{~kg} \mathrm{~m}^{-3}$ (difference 20.6\%).

The difference between mean SD and SWD values (Table 3) shows that among tree species, the oven-dry stem bark is less dense than wood for

Summary of fit statistics and parameter estimates

Table 2

\begin{tabular}{|c|c|c|c|c|c|}
\hline & \multicolumn{3}{|c|}{ Parameter values } & \multirow{2}{*}{$\mathrm{R}^{2}$} & \multirow{2}{*}{$\begin{array}{c}\text { SE } \\
\mathrm{kg} \mathrm{m}^{-3}\end{array}$} \\
\cline { 2 - 5 } & $\beta_{1}$ & $\beta_{2}$ & $\beta_{3}$ & & 28.5 \\
\hline Pinus sylvestris & 441.423 & 0.691 & 0.089 & 0.67 & 30.6 \\
\hline Picea abies & 418.551 & 0.291 & 0.048 & 0.27 & 26.4 \\
\hline Betula spp. & 528.197 & 0.354 & 0.104 & 0.54 & 26 \\
\hline
\end{tabular}

$\mathrm{R}^{2}$ - coefficient of determination, $\mathrm{SE}$ - standard error of the regression. 

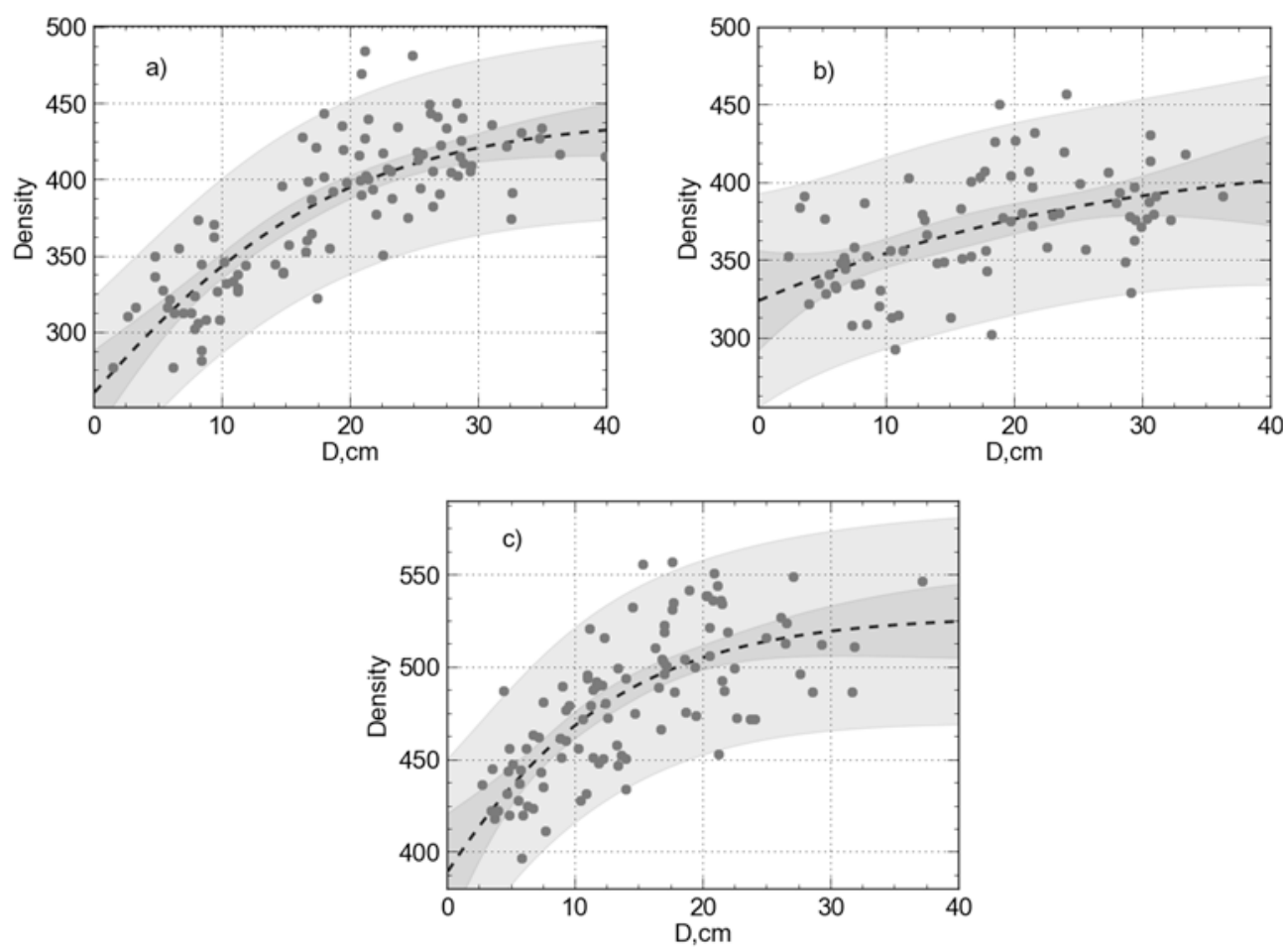

Figure 3. Relationship between average stem basic density $\left(\mathrm{kg} \mathrm{m}^{-3}\right)$ and diameter for pine (a), spruce (b) and birch (c) stems according to the derived model. For all regressions, the confidence bands (dark grey) and prediction bands (light grey) at 95\% confidence level are displayed.

coniferous species but for birch bark is more dense than wood.

The Intergovernmental Panel on Climate Change (Eggleston et al., 2006) guidelines suggest the use of mean wood density values of $420 \mathrm{~kg} \mathrm{~m}^{-3}$, $400 \mathrm{~kg} \mathrm{~m}^{-3}$ and $510 \mathrm{~kg} \mathrm{~m}^{-3}$ for pine, spruce and birch, respectively, to estimate the wood biomass. Our results indicate that this approach for the studied tree species is leading to the overestimation of stem biomass for young trees because the suggested density values are correct for mature trees. Dibdiakova \& Vadla (2012) found significant differences $(\mathrm{p}<0.05)$ in bark density along the stem of Sitka spruce. In the aforementioned study, the bark density was reported higher than the wood density only on the base of trees. It has been reported in Latvia that bark density of Scots pine along the stem increases from
$385 \mathrm{~kg} \mathrm{~m}^{-3}$ from the stump to $575 \mathrm{~kg} \mathrm{~m}^{-3}$ to the top (Millers \& Magaznieks, 2012). Little information is available on variations of bark density for the studied tree species, highlighting the need for further investigations.

\section{Conclusions}

1. Pine and birch demonstrate strong vertical dependence in SWD, but for spruce the variation pattern is less pronounced and seems to be nearly constant.

2. The SWD, estimated with Repola's models, was $4.3 \%$ lower for spruce but $3.4 \%$ and $2.2 \%$ higher for pine and birch, respectively.

3. Tree D explains $67 \%, 27 \%$ and $54 \%$ of the variations in SWD for pine, spruce and birch, respectively.

Table 3

Pine, spruce and birch stemwood and bark basic densities (average values and standard deviation), $\mathrm{kg} \mathrm{m}^{-3}$

\begin{tabular}{|c|c|c|c|}
\hline & SD & SWD & SB \\
\hline Pinus sylvestris & $380.5 \pm 48.2$ & $397.3 \pm 49.0$ & $260.1 \pm 24.0$ \\
\hline Picea abies & $368.9 \pm 36.7$ & $378.0 \pm 35.4$ & $295.5 \pm 27.5$ \\
\hline Betula spp. & $481.7 \pm 46.5$ & $470.3 \pm 38.5$ & $551.2 \pm 36.7$ \\
\hline
\end{tabular}

SD - mean stem density, SWD - stemwood density, SB - stem bark density. 
4. From studies, the tree species birch has the highest basic SWD $-470 \mathrm{~kg} \mathrm{~m}^{-3}$, being lower for coniferous species $-397 \mathrm{~kg} \mathrm{~m}^{-3}$ for pine and 378 $\mathrm{kg} \mathrm{m}^{-3}$ for spruce.

5. The mean stem with bark basic density for pine, spruce and birch are $380 \mathrm{~kg} \mathrm{~m}^{-3}, 368 \mathrm{~kg} \mathrm{~m}^{-3}$ and $481 \mathrm{~kg} \mathrm{~m}^{-3}$, respectively.

6. According to our results, the birch bark turned to be denser than the birch stemwood, being vice versa for the studied coniferous species.

\section{Acknowledgements}

The study is conducted within the memorandum 'On cooperation in scientific research' between Joint Stock Company 'Latvia's State Forests' and LVMI 'Silava' signed in 11.10.2011.

\section{References}

1. Birch, C.P.D. (1999). A New Generalized Logistic Sigmoid Growth Equation Compared with the Richards Growth Equation. Annals of Botany, 83, 713 - 723. DOI: 10.1006/anbo.1999.0877.

2. Cabeza, L.F., Barreneche, C., Miró, L., Morera, J.M., Bartolí, E., \& Inés Fernández, A. (2013). Low carbon and low embodied energy materials in buildings: A review. Renewable and Sustainable Energy Reviews, 23(july), 536 - 542. DOI: 10.1016/j.rser.2013.03.017.

3. Chave, J. (2005). Measuring wood density for tropical forest trees. Sixth Framework Programme (2002 - 2006). Toulouse, France. Retrieved October 13, 2017, from: http://www.rainfor.org/upload/ ManualsEnglish/wood_density_english[1].pdf.

4. Dibdiakova, J., \& Vadla, K. (2012). Basic density and moisture content of coniferous branches and wood in Northern Norway. In: 2nd European Energy Conference. EPJ Web of Conferences 33(02005), 6 pp. DOI: 10.1051/epjconf/20123302005.

5. Eggleston, H., Buendia, L., Miwa, K., Ngara, T., \& Tanabe, K. (2006). 2006 IPCC Guidelines for National Greenhouse Gas Inventories, Prepared by the National Greenhouse Gas Inventories Programme.Volume IV Agriculture, Forestry and other land-use. IGES, Japan.

6. Gustavsson, L., Pingoud, K., \& Sathre, R. (2006). Carbon dioxide balance of wood substitution: Comparing concrete- and wood-framed buildings. Mitigation and Adaptation Strategies for Global Change, 11(3), 667 - 691. DOI: 10.1007/s11027-006-7207-1.

7. Hakkila, P. (1998). Utilization of Residual Forest Biomass. Berlin: Springer.

8. Henry, M., Besnard, A., Asante, W.A., Eshun, J., Adu-Bredu, S., Valentini, R., ... Saint-André, L. (2010). Wood density, phytomass variations within and among trees, and allometric equations in a tropical rainforest of Africa. Forest Ecology and Management, 260(8), 1375 - 1388. DOI: 10.1016/j.foreco.2010.07.040.

9. Herajarvi, H. (2004). Variation of basic density and brinell hardness within mature finnish betula pendula and b. pubescens stems. Wood and Fiber Science, 36(2), 216 - 227.

10. Ilic, J., Boland, D., McDonald, M., Downes, G., \& Blakemore, P. (2000). Woody density: Phase 1 - State of knowledge. NCAS technical report no.18. Retrieved October 13, 2017, from: http://www.fullcam. com/FullCAMServer/Help/reps/TR18\%20Woody\%20Density\%20Phase\%201\%20-\%20State\%20of\%20 Knowledge.pdf.

11. Jyske, T., Mäkinen, H., \& Saranpää, P. (2008). Wood density within Norway spruce stems. Silva Fennica, 42(January), $439-455$.

12. Kofman, P., \& Kent, T. (2007). Harvesting and Processing Forest Biomass for Energy Production in Ireland. The ForestEnergy 2006 Programme. Dublin: COFORD.

13. Liepins, K., \& Rieksts-Riekstins, J. (2013). Stemwood Density of Juvenile Silver Birch Trees (Betula pendula Roth) from Plantations on Former Farmlands. Baltic Forestry, 19, 179 - 186.

14. Liepiņš, J., \& Liepiņš, K. (2015). Evaluation of bark volume of four tree species in Latvia. In Research for Rural Development - International Scientific Conference. Vol. 2, (pp. 22 - 28). Jelgava: LLU.

15. Millers, M., \& Magaznieks, J. (2012). Scots Pine ( Pinus sylvestris L .) Stem Wood and Bark Moisture and Density Influencing Factors. In Research for Rural Development - International Scientific Conference. Vol. 2, (pp. 91 - 98). Jelgava: LLU.

16. Petersson, H., \& Stahl, G. (2006). Functions for below-ground biomass of Pinus sylvestris, Picea abies, Betula pendula and Betula publescens in Sweden. Scandinavian Journal of Forest Research, 21(7), 84 93. DOI: $10.1080 / 14004080500486864$.

17. Pödör, Z., Manninger, M., \& Jereb, L. (2014). Application of sigmoid models for growth investigations of forest trees. Advances in Intelligent Systems and Computing, 282(May), 353 - 364. DOI: 10.1007/978-3319-06569-4_26. 
18. Repola, J. (2006). Models for vertical wood density of Scots pine, Norway spruce and birch stems, and their application to determine average wood density. Silva Fennica, 40(July), 673 - 685.

19. Repola, J. (2008). Biomass equations for birch in Finland. Silva Fennica, 42(4), 605 - 624.

20. Repola, J. (2009). Biomass equations for Scots pine and Norway spruce in Finland. Silva Fennica, 43(May), $625-647$.

21. Rikala, J. (2003). Spruce and Pine on Drained Peatlands Wood Quality and Suitability for the Sawmill Industry. University of Helsinki, Department of Forest Resource Management, Publications $35.147 \mathrm{p}$.

22. Saranpää, P. (2003). Wood density and growth. In J.R. Barnet \& G. Jeronimidis (Eds.), Wood quality and its biological basis. (pp. 87 - 118). Boca Raton, FL: CRC Press.

23. Singh, T. (1984). Variation in the Ovendry Wood Density of Ten Prairie Tree Species. The Forestry Chronicle.

24. Skovsgaard, J.P., Bald, C., \& Nord-Larsen, T. (2011). Functions for biomass and basic density of stem, crown and root system of Norway spruce (Picea abies (L.) Karst.) in Denmark. Scandinavian Journal of Forest Research, 26(11), 3 - 20. DOI: 10.1080/02827581.2011.564381.

25. Smith, A., Granhus, A., Astrup, R., Bollandsås, O.M., \& Petersson, H. (2014). Functions for estimating aboveground biomass of birch in Norway. Scandinavian Journal of Forest Research, 29(6), 565 - 578. DOI: $10.1080 / 02827581.2014 .951389$. 